\title{
The hesychasm movement and the franciscan spirituality
}

\author{
Liviu-Octavian MARINA-FIȚ*
}

Abstract: Uninterrupted prayer has been one of the aspirations of Christianity ever since its beginnings. When we are talking about the hesychasm movement, we cannot ignore what is commonly known as the ,prayer of the heart” or ,the prayer of Jesus." It is difficult to determine the origin of the practice of this prayer; perhaps its appearance is confused with that of Christian monachism that has guessed in the uninterrupted prayer embodied in the invocation of the Name of Jesus, a remnant of the original Christianity. Among those who have tried to accomplish this goal there were not only many eastern monks, but also some western monks. This study shows that the same Holy Spirit determined similar behaviors and attitudes to the understanding and practice of this type of prayer both in the East, in the Hesychasm movement and in the West, in the Franciscan spirituality.

Keywords: hesychasm, silence, the name of Jesus, Abba, divine light.

\section{Introduction}

In the Semitic mentality, the name generally meant the secret nature of a human being, not by virtue of a definition of its symbol, but because the name contained some sort of active

* PhD Candidate, Faculty of Orthodox Theology at the "1 Decembrie 1918" University, Alba Iulia, Romania. 
presence. Where there is the Name, there is the Person with its „power”, ready to manifest itself. To know someone „by name” meant to know him in his intimacy; so knowing the Divine Name was equivalent to having an exceptional power, because it possessed the means by which you could make yourself heard by the divinity and you could capture its benevolence. The invocation of the divinity by name, in a loud voice, it was probably the most solemn act of all archaic religions ${ }^{1}$.

The apostolic community, having resumed an old-testament tradition, it had, from the beginning, a very special attention to the Name that the Son of God that he took once with its incarnation: Jesus, who means the Savior. In the Holy Scripture we found three texts that highlight the veneration that the Primary Church had with the name of Jesus ${ }^{2}$. This biblical veneration for Name is the base and foundation of Jesus' prayer. The name of

* PhD Candidate, Faculty of Orthodox Theology at the "1 Decembrie 1918" University, Alba Iulia, Romania.

${ }^{1}$ Jean-Yves Leloup, The Hesychasm - what is it and how it lives, translation from French into Italian by Rosalba Giugni, Torino, Piero Gribaudi Editore, 1992, p. 154.

${ }^{2}$ Philippians 2, 9-10: „Wherefore God also hath highly exalted him, and given him a name which is above every name: That at the name of Jesus every knee should bow, of things in heaven, and things in earth, and things under the earth".

The Acts of the Apostles 4, 10-12: „Be it known unto you all, and to all the people of Israel, that by the name of Jesus Christ of Nazareth, whom ye crucified, whom God raised from the dead, even by him doth this man stand here before you whole. This is the stone which was set at nought of you builders, which is become the head of the corner. Neither is there salvation in any other: for there is none other name under heaven given among men, whereby we must be saved".

John 16, 23-24: „, And in that day ye shall ask me nothing. Verily, verily, I say unto you, Whatsoever ye shall ask the Father in my name, he will give it you. Hitherto have ye asked nothing in my name: ask, and ye shall receive, that your joy may be full". 
God is united indissolubly with the Person, and thus the invocation of the Divine Name possesses a sacramental character and is the effective sign of its invisible presence and action ${ }^{3}$. Philocalic literature also states that ,the naming of the name of God stops all evils and strengthens our infirmity"4. And St. John Climacus recommends: „Destroy your enemies with the name of Jesus because it is not a stronger weapon in heaven and earth ... Jesus' memory to be united with every breath of yours and then you will experience the value of peace" 5 .

\section{General aspects of the hesychasm concept}

The prayer of the heart, rooted in the New Testament, is assumed by an actual current of ancient oriental spirituality, which has been called the hesychasm ${ }^{6}$. The name derives from the Greek hesycia term ${ }^{7}$, which means: calm, peace, quiet. The

${ }^{3}$ Kalistos Ware, The Power of the Name: The Jesus Prayer in Orthodox Spirituality, 1986, translate from English into Italian by Elisabetta Capello and Marino Clerico, in Elisabeth BEHR-SIGEL, The place of the heart. Initiation to Orthodox spirituality, Milan, Paoline Editions, 1993, p. 131.

${ }^{4}$ Saints VarsanufIE AND John, Spiritual Letters [col. Philocalia, vol. XI], translation from Greek, introduction and notes by Dumitru Stăniloae, Bucharest, Humanitas Publishing House, 2009, p. 557 (question 692).

5 Saint John Climacus, The Ladder of Divine Ascent. The book about the needs [col. Philocalia, vol. IX], translation from Greek, introduction and notes by Dumitru Stăniloae, Bucharest, Humanitas Publishing House, 2011, Word XI and Word XXVII.

${ }^{6}$ John Moldoveanu, Bibliography of the Romanian hesychasm, available on www.unibuc.ro/prof/moldoveanu_i/docs/res/2012ianIsihasmul.doc (accessed on 03.08.2018).

${ }^{7}$ Generally, hesychia means tranquility, but it can also express deep peace of heart. The etymology is uncertain: perhaps the verb from which this term derives is to be seated, to sit. In monastic literature, hesychia has at least two meanings: first of all peace and quiet as a state of soul and a stable condition necessary for the heart to contemplate; Secondly, breaking the world, that is, loneliness and silence. 
Hesychasm can be defined as a purely contemplative spiritual system that seeks man's perfection in union with God through unceasing prayer. What characterizes this movement is certainly the affirmation of the perfection or necessity of the hesychia (peace) in order to reach peace with God. In a document of the Iviron Monastery in Mount Athos, one reads this definition: „Hesychast is the one who speaks to the one God and pray to Him without ceasing"8.

Hesychia expressed in peace, tranquility, solitude, and inner silence, which is gained by loneliness and outer silence, presents us as a very good means of reaching the ultimate goal of man: uniting with God in contemplation, by unceasing prayer. Being not an end in itself, the hesychia must be distinguished by the Stoics apàtheia, understood as absent and free from the four fundamental passions: sadness, fear, desire and pleasure; it must also be distinguished from the epicurean ataraxia, understood as releasing of the soul from the preoccupations of life. These philosophical movements emphasize and seek the peace and quiet of the soul, only as the ultimate end and not as a means for a complete life that only God can give ${ }^{9}$.

To include the various aspects of the hesychia that the monk is called to experience, we might refer to the life of St. Arsenius, the father of the anahoreths. Here is how his hesychia's vocation is presented: „Avva Arsenius, still in the royal palaces, prayed to God, saying: «Lord show me the way, that I may know how I will save» And a voice came to him, saying: «Arsenius, run away from people, and you shall be saved». He, after going to the hermitage, again prayed, the same word saying. And he heard the

${ }^{8}$ Tomáš ŠPIDLíK, „The Hesychast”, in Guerrino PelliCCIA / Giancarlo RocCA (eds. / coord.), Dictionary of Institutes of Perfection, vol. III, Rome, Paoline Editions, 1976, p. 1312-1313.

${ }^{9}$ Marcello BRUNINI, The prayer of the heart in the spirituality of the Christian East, Padua, Messaggero Editions, 1997, p. 89. 
voice saying to him: «Arsenius, run, shut up, be quiet; that they are the roots of uncleanness»" $"$.

This last sentence is the beginning of the hesychastic vocation: „Run, shut up, be quiet!” The fleeing of the world, silence and inner peace are the three realities that illustrate the life of the monk, especially of the anchorite. The authentic monk is called first of all to live in solitude. Parents of the wilderness emphasize the crucial importance of the running away from people, the need to minimize contact with them. It is said in this regard:

„Once came the blessed Theophilus, the Archbishop of Alexandria, with a governor at the Abba Arsenius and asked the old man to hear from him the word. And the old man, waiting for a while, replied: «If I tell you a word, will you keep it?» And they promised to keep him. And the old man said to them: «Wherever you shall hear that it is Arsenius, do not come closer»" $"$.

„Abba Mark says to Abba Arsenius: «Why are you running away from us?» The old man says: «God knows that I love you, but I cannot be with both, men and God. The ones from above, thousands and tens of thousands, have one will, and people have man wills. So I cannot leave God and come with the people»" $"$.

Hesychia as silence is not just about running away from the world but also indicating stability in a determined solitary place. This exigency is expressed by a famous formula, which became later traditional: „Go, sit in your hermitage and the hermitage will teach you all"13. „He will teach you all” is the same phrase we find on the lips of Christ when He announces the coming of the

10 *** Egyptian patericon, Alba Iulia, Reîntregirea Publishing House, 2014, p. 18, For avva Arsenie 1, 2.

${ }^{11}$ Ibidem, p. 18-19, For abba Arsenie 7.

${ }^{12}$ Ibidem, p. 19, For abba Arsenie 13.

${ }^{13}$ Ibidem, p. 168, For abba Moses 6. 
Holy Spirit ${ }^{14}$. Abba Macarious the Egyptian puts together the escape of people with the remaining in the hermitage: „Abba Isaiah asked Abba Macarious, saying: «Tell me a word». And the old man said to him: «Run away from people». Isaiah asked him: «What is to run away from people? » And the old man said to him: «Means to sit in your hermitage and to cry for your sins»»"15.

And answering to abba Aio, the same Abba Macarius the Egyptian said: „Run away from people, sit in your hermitage and cry your sins. Do not love people, so you save yourself" 16 .

The fact that the hermitage is the right environment for the hesychia will also be said by St. Anthony the Great: „Like the fish, remaining for a long time on land, they die, so the monks, lulling out of the hermitage or spending time with people, are weakened by the power of peace. Therefore, like fish to the sea, we must to hurry to the hermitage; lest we dwell outside, forget the inner caress" 17 .

Even if the hermitage is very important, you cannot stay in it with a spirit of the owner ${ }^{18}$. The monk knows that he is a

${ }^{14}$ John 14, 26: „But the Comforter, which is the Holy Ghost, whom the Father will send in my name, he shall teach you all things, and bring all things to your remembrance, whatsoever I have said unto you".

15 *** Egyptian patericon, p. 162, For abba Macarious the Egytian 26.

${ }^{16}$ Ibidem, p. 167, For abba Macarious the Egytian 39.

${ }^{17}$ Ibidem, p. 167, For abba Anthony 12.

${ }^{18}$ Ibidem, p. 167, For abba Agathon 6: „some people says that Abba Agathon spent much time building a hermitage with his disciples, and when they had finished their hermitage, they came to sit in it. And the old man saw in the first week that he did not use it, and said to his disciples: «Get up, let us go from here». And they were disturbed saying: «If it had an account to move us, why have we made so much trouble building the hermitage? And the men will think about us: Look, they moved again, unfaithful» And when he saw them low with their own soul, he said to them: «Though some will be rebuked, others will be built, saying: Blessed are some like these, 
stranger on this earth, and therefore he renounces to everything that could prevent him to stop from the true service of God, living in secret and waiting, hoping intense in the second coming of the victorious Lord. External solitude is certainly important, but much more necessary is the solitude of the heart. This is where true hesychia, eremitical life or inner a anachoresis, the monasticism of the heart, is the only one that can lead to the prayer of Jesus.

In loneliness, the monk is called to live peace; the parents of the wilderness express a silence that is „with thousands of names and thousands of faces, where each thing is in its place, it is a quiet silence for the soul, a tranquility that has something transcendental in it. From the many aphorisms it is clear that the tranquility of the wilderness's parents is a silence in humility, a quietness to themselves, a silence that removes the words of egoism, pride, self-love, it is the silence of the one who becomes a pilgrim and a stranger, but also a quiet of love, a silence of the one who does not judge the neighbor, the one who does not talk or criticize others, in finally it is a quiet of faith, of the one who trusts God in whose hands he is entrusted"19.

Quietness is like a hermitage from which the man of prayer will never come out, even if from love he will sometimes have to come out of the visible hermitage in which he lives ${ }^{20}$. The real

that they have moved for God and have defamed them all. But the one who want to come, to come now, because I am moving». And they were thrown to the ground, praying until they were forgiven, to travel together with him".

${ }^{19}$ Massimo BALDINI, The silent in the Desert Fathers, Vicenza, La Locusta House Publishing, 1987, p. 18.

$20 * * *$ Egyptian patericon, p. 211, For abba Pimen 84: „If you remain silent, you will have rest in the place where you live". 
escape of people is when you manage to keep quiet even if you have the opportunity to talk; this is true alienation (xenitèia $)^{21}$.

The silence to which parents of the wilderness invite is also a confession at the same time. After their experience, it is necessary to speak with facts not with the tongue. When faith is seen in deeds, words are superfluous ${ }^{22}$. In the words of the wilderness's fathers, there are riminded more gifts that silence generates. Thus silence gives tranquility, keeps chastity, is helpful against to those from the world, keeps the soul in peace; silence helps not to judge the neighbor, not condemning anyone, being a remedy against evil words; is a school of tolerance and benevolence towards all $^{23}$. Such silence without going to judge requires a lot of courage ${ }^{24}$.

The loneliness and silence practiced in the concrete way is therefore for the desert parents the fundamental moment of the body's hesychia, of the exterior hesychia. A tranquility which, even outside, is very much needed. In fact Avva Macarie said:

${ }^{21}$ Ibidem, p. 273, For abba Tithoe 2: „Abba Tithoe said: alienation is to control human's mouth".

${ }^{22}$ Ibidem, p. 255, For abba Sisoe 45: „A brother asked Avva Sisoe, saying: «Tell me a word». And he said unto him: «Why do to hail me to speak in vain? Look, do what do you see!»";

${ }^{23}$ Ibidem, p. 38, For abba Ammona 8: „To this abba Ammon, Anthony command, saying: "You will grow up in the fear of God». And casting him out of the hermitage, he showed him a stone, and said to him: Argue this stone, and beat it». And he did that. And abba Anthony said to him: «Did not the stone talk?» And he said: «No». Again abba Anthony says to him: «You will also get to this measure». What has been done, abba Ammona has increased so much that he has no knowledge of what is wicked..."

${ }^{24}$ Ibidem, p. 220, For abba Pimen 139-140: „Abba Pimen said: «If you will see a few things and you will hear words, do not tell them to your neighbor, because is landslide for war». / He said again: «First and second time, run! For the third time become sword!»". 
„No one can have the soul's hesychis, unless it is first assured with the one of the body" 25 .

Of course, however, inner hesychis is the essential foundation of oriental monastic spirituality. From loneliness and the absence of words, the monk is called to go into profound active and creative silence, which is totally different from quietism, a doctrine that recommends acquiring the peace of mind by adopting a passive and contemplative attitude towards the world. The wilderness fathers frequently reminded that even after the first retreat in the wilderness, Christ sought for loneliness several times, which affirms the connection between solitude and prolonged prayer. When Jesus' prayer becomes the prayer of the heart of the hesychast, the first effect it produces is the enlightenment of the heart and mind through the ,sight” of God, contemplated in love.

Theology of light occupies an important place in the life of the Oriental Church. In the Divine Liturgy everything is light: the whole church is enlightened, the Holy Sanctuary and the royal icons have candles, and when serving the bishop he adds more brilliance to the cult with the blessings made with the dicher and tricher. The gold and silver of the apparel and liturgical objects reflect all these lights. The oldest known hymn of the Oriental Church is „Soft Light” (2nd century). The greatest celebration over the year is the Easter, the Light of the Resurrection. The feast of the Transfiguration is a solemn feast of Orthodoxy because it is a fundamental theme of Oriental Christian spirituality and mentality. The Orthodox saints receive the grace

${ }^{25}$ Louis LELOIR, Desert and communion: the Fathers of the desert and their message today, presentation by Enzo Bianchi, translate from French into Italian by Maria Paronelli, Turin, Gribaudi Edition, 1982, p. 84. 
of transfiguration to the point that this is sometimes visible even on their face ${ }^{26}$.

The spiritual and inner light can sometimes become visible in a charismatic manner. It is a transfiguration of the body, the participation in that light in which Christ was transfigured on Mount Tabor. That is why this light is called by the hesychasts theologians the taboric light, which is a familiar theme in the language of the Oriental mysticism, especially in the hesychasm. The light of transfiguration, prefigured on Mount Sinai on the face of Moses, irradiated in all its splendor on Tabor in the person of Christ, announces the parousia, the resurrection, the new world. This divin reality is already present for the Christian in sacramental life and in spiritual experience. The hesychast monk, transfigured by Jesus' prayer, has the feeling, sometimes physically, of a light (the taboric light) that envelops him. This light is the external sign of the deification of man through Christ $^{27}$.

\section{The franciscan spirituality}

Analyzing the theme of the prayer at St. Francis of Assisi we find many points in which it resembles the tradition of the Orthodox Church and especially the way of understanding the prayer in the environment of the hesychast. This conclusion was reached by the Jesuit Tomáš Špidlik, a very good connoisseur of Oriental spirituality: „The hesychast tendency can surely reckon

${ }^{26}$ Yannis SPITERIS, Francis and the Christian East. A comparison, Rome, Historical Institute of the Capuchins Edition, 1999, p. 85.

${ }^{27}$ It can be read in the stories about the life of St. Sisoe that he was on the deathbed, the brothers gathered around him and his face shone like the sun ... then that splendor of his face had doubled ... and the whole house it was filled with good fragrance. 
St. Francis among her followers" 28 . Also, Leonhard Lehmann, the most important researcher of the Franciscan prayer, is convinced that the prayer of St. Francis is contemplative and we can call it „the prayer of the heart" 29 .

A first characteristic of St. Francis' prayer is continuity. In the last part of the Unconfirmed Rule [Regola non bollata] he begs the brothers to have an unceasing prayer:

„Anywhere, everywhere, every hour, any time, every day, endlessly, we all really and humblely believe and hold on to the heart, to love, to honor, to worship, to serve, to praise and to bless, praise and to thank the eternal and exalted God, the Trinity and the Unity, the Father and the Son and the Holy Spirit, the Creator of all and the Savior of all those who believe and hope in Him, and love Him, the One without the beginning and the end" 30 .

And in the Letter to the believers [Lettera a tutti i fedeli] recommends:

„Let us therefore love God, and worship him with pure heart and with pure mind, because He himself, seeking this above all things, said, The true worshipers will adore the Father in spirit

28 Tomáš ŠPIDLÍK, „The prayer of the heart. A comparison between East and West", in Yannis SPITERIS / Bruno GIANESIN (coord.), Seeing God. Meeting between East and West, Bologna, Dehoniane Editions, 1994, p. 75.

${ }^{29}$ Leonhard LEHMANN, Francis, teacher of prayer, translation from German into Italian by Flaviano Premoli and Pietro Maranesi, Rome, Historical Institute of the Capuchins, 1993, p. 31-35.

30 SAN FRANCESCO D'ASSISI, Unconfirmed Rule XXIII, 32-34, in Feliciano OlgIATI et alii (eds. / coord.), Franciscan sources. Writings and biographies of St. Francis of Assisi. Chronicles and other testimonies of the first Franciscan century. Writings and biographies of St. Clare of Assisi [Fonti Francescane. Scritti e biografie di san Francesco d'Assisi. Cronache e altre testimonianze del primo secolo francescano. Scritti e biografie di santa Chiara d'Assisi], Padua, Messaggero Editions, 1982, (hereafter $F F$ ) 71, pp. 121-122. 
and truth. For all who adore it, in spirit and in truth, must adore Him. And let us hymns and praise it day and night, saying: Our Father, who art in heaven, because we must always pray without ceasing" 31 .

Chapter LXI in the work of St. Francis's biographer, Tommaso da Celano, entitled Life of St. Francis of Assisi Second Edition [Vita Seconda], is a hymn dedicated to the love's saint for prayer. It looks like the description of a hesychast contemplation. St. Francis not only prays in hermits for days and weeks, but often ,closes in the cell of his own heart”. Here's what the saint's biographer says:

,...absorbed in God and forgetting himself, not moaning, noy coughing [that is, interrupting any form of external manifestation], his breathing disappeared with any other external sign ... often without moving his lips, meditating for a long time, concentrating inside his external powers, rises with the spirit to heaven. In this way, he directed all the mind and affection to that single thing he demanded from God: not so much a man who prayed as much as he himself was transformed entirely into living prayer" 32 .

St. Francis' attachment to prayer could be expressed by the words of Leonhard Lehmann who asserted with reference to this aspect: ,The Word of God in heart and heart in God"33. Often, referring to many passages in the Scriptures, St. Francis urges the brothers to guide their hearts to God to make it a good place for God and His word ${ }^{34}$. The heart is the center of man, the center of his decisions. In the heart lives either God with His word or Satan. Under these conditions, prayer is more than a theoretical

${ }^{31}$ IDEM, Letter to the believers 19-21, in FF 187-188, p. 152-153.

${ }^{32}$ Tommaso da Celano, Second life 94, in FF 681, p. 629-630.

${ }^{33}$ Leonhard LEHMANN, op. cit., p. 31.

${ }^{34}$ See chapter XXI from SAN FRANCESCO D'ASSISI, Unconfirmed Rule, in FF 56-62, p. 116-119. 
meditation on God and more than a string of words. On the contrary, it is a way of maintaining love with God, a permanent connection with Him.

St. Francis demandes to his brothers that this inner prayer be continuous, even during the work they have to do, insisting on the importance of the quality of being made with a pure heart: „Those brothers to whom the Lord has given grace to work, to work with fidelity and godliness, so that by removing laziness, the enemy of the soul, will not extinguish in them the spirit of holy prayer and piety, to whom all the other passers-by must serve" $" 35$.

The constant preoccupation of all the brothers should be that, leaving aside all care, ,to serve Him, to love Him, to honor Him, and to worship the Lord God with a pure heart and an undefined mind, what He himself demands above all"36.

Elsewhere, it is explain who is the one who has the ,pure heart”: „Truly, they are cleansed with heart, those who despise earthly things, seek heavenly things, and with the heart and the pure soul, not cease to worship and see the Lord, the living and true God"37.

The cleansing of the heart for St. Francis is the liberation from earthly things, which the hesyshasts name amerimnia. It is the separation of all to have just God and to be related only to Him as the only good of his own life. This is obviously one of the fundamental beliefs, one of the most important religious experiences of St. Francis, which he sought both in the Holy Scripture and in his own life: where man enters the work of God, where he freely opens the work of the saving grace of God, where

${ }^{35}$ SAn FranCESCO D'Assisi, Confirmed rule, V, 1-3, in FF, p. 126.

${ }^{36}$ IDEM, Unconfirmed rule XXII, 26, in FF 60, p. 118.

${ }^{37}$ IDEM, Admonitions 16, in FF 165, p. 144. 
God who is love becomes the only love of his life, man becomes happy because he sees $\operatorname{God}^{38}$.

The writing in which the most commonly used phrase ,to see God" appears is Admonitions, in Chapter 1, where the term is used for not less than thirteen times. The influence of St. John the Evangelist is noted, from which several quotations were taken, especially from chapter XIV of his gospel; the whole of this first chapter in the work of St. Francis, which speaks of the Body of the Lord, is structured in the relationship of seeing - believing, or seeing - not believing.

For St. Francis to worship God is to see Him in contemplation through the pure heart. So the view of God theōria - is not interpreted as intellectualistic but practical, as Oriental Fathers also said. At S. Francisc, the ,pure heart” is the sensible and intellectual overthrow of the experience with God, and lies within the divine free space that leads him to a constant „vision” of God in the „clean” prayer ${ }^{39}$.

The prayer of St. Francis was also a brief and repetitive prayer: „More than in ample formulas, the affective prayer of the heart can be expressed in short prayers, frequently repeated, in prayers launch to heaven, in exclamations and sighs" ${ }^{40}$.

The prayer of praise to God the Most High is nothing more than a collection of short prayers filled with fervor in the form of praise to the Lord. There is no thought here to represent the red thread of prayer, but it is a series of names of God: „1. You are Holy Lord, the only God who does wonderful things. 2. You are strong. You are hard. You are high. 3. You are the Emperor's powerfull. You are the holy Father, the King of heaven and earth.

${ }^{38}$ Kajetan ESSER, Admonitions of S. Francis, Rome, A.S.S.C. Editions, 1982, p. 227-228.

${ }^{39}$ Yannis SPITERIS, op. cit., p. 93.

${ }^{40}$ Leonhard LEHMANN, op. cit., p. 33. 
4. You are also threefold and the One, the Lord God of gods. 5. You are the good, the good, the supreme good, the Lord, the living and true God. 6. You are love, charity. You are wisdom. You're humility. 7. You are patient. You are beautiful. You are safe. You are peace. 8. You are joy and happiness. You are our hope. 9. You are right. You are temperament. You are all our rich. 10. You are beautiful. You are gentle. 11. You are the protector. You are our watchdog and defender. You are strong. You are escaping. 12. You are our hope. You are our faith. You are our charity. You are all our sweetheart. 13. You are our eternal, great and wonderful life, Lord God Almighty, Merciful Savior" ${ }^{4}$.

The biographies of the Saint, on the other hand, clearly certify that Francis prefers the short form of prayer. Fioretti tells that brother Leon ", hear the voice of St. Francis and, approaching, he saw him standing on his knees in prayer with his face and hands raised to the sky and the fervor of the spirit he said. "Who are you, my God, my sweet God? Who am I, a wicked worm, and an useless servant of Your?» And these words repeated them and said nothing else. That is why brother Leon, wondering very much about this, raised his eyes and looked up at the sky; and seeing a very beautiful and splendid flame of fire coming down from the sky, which descended upon St. Francis' head; and from this flame he heard a voice speaking with St. Francis" $^{\prime \prime 2}$.

In this confession, we find a short and exclamatory prayer that contains the two basic feelings of the hesychast prayer: the admirable belief that praises the power of God and the finding of its own sinful condition. In this text is also witnessed the

${ }^{41}$ San FrancesCo D'Assisi, Praise of God Most High, in FF 261, p. 176-177. 42 *** I Fioretti by S. Francis, in FF 1915, p. 1593-1594. 
enlightenment of St. Francis from sky, a phenomenon that characterizes certain Fathers of the hesychast tradition.

Also from the same source of the Acts of Blessed Francis comes the very well-known expression „Deus meus et omnia” (to translate „My God and My All” or better „My God and All Things") ${ }^{43}$.

Just as in the case of the hesychasts, at St. Francis prayer often embraces the form of regret and forgiveness for the sins committed. Tommaso da Celano, the biographer of St. Francis, tells that while the Saint was at Poggio Bustone, wishing to know the future of the monastic order, ,he retired, as he often did, in a suitable place for prayer. He lingered for a long time invoking with fright and fear the Ruler of the whole earth, thinking bitterly about the years spent in sin and repeating: «God, be benevolent to me, the sinner!»" Little by little he felt flooded in the intimacy of his heart with an ineffable happiness and a huge sweetness ... Then, as if he had been kidnapped and transported in great light, expanding the space of his mind, he could to contemplate freely the future" 44 .

In this text, we find almost identical the formula of the hesychast prayer that expresses in a very clear way the regret of the heart, an indispensable condition for continual prayer. On the other hand, St. Francis's frequent references to „making penance” have no purpose but to cultivate in the hearts of his brothers the spirit of regret and the metanoia that accompany any of the hesychast. The term ,penitence” is found in the writings of St. Francis 28 times: 18 times with the meaning of metanoia in the preaching of the Gospel, and 10 times with the meaning of the Holy Mystery of Repentance. For St. Francis to „make penance” indicates the fundamental attachment to faith, which distinguishes

${ }^{43}$ Leonhard LeHMANN, op. cit., p. 255.

${ }^{44}$ TOMmASO da Celano, First life of St. Francis of Assisi 26, in FF 363, p. 432. 
the true believer from the false. In the first case, the one who repents is the Christian who made a choice for God and for the brothers; in the second case, the one who does not repent is the one who made a selfish choice for himself and for the devil ${ }^{45}$. Only those who repent can have a very intimate relationship with the Lord because ,the Spirit of the Lord rests upon them, and will make them sanctuary and dwelling there, and they are the sons of the heavenly Father, whose deeds are fulfilled and are grooms, brothers and mothers of our Lord Jesus Christ" $" 46$. Here is what St. Gregory Palamas called ,deification transformed into a permanent contemplation", a charisma much desired by those who are taught with the hesychast prayer.

Even though almost all of St. Francis's prayers are centered on the Holy Trinity and have as their starting point the Person of God the Father, yet he is in love with the name of Jesus and addresses frequent prayers. As he himself states in his Testament: „And the Lord gave me such a faith in churches that I simply prayed and said: «We worship You Lord Jesus Christ, and in all your churches that are in the world, and bless you, because through your holy cross you have redeemed the world»" "47.

As noted by Lehmann, the well-known liturgical prayer Adoramus Te, Christe ... St. Francis added to him the words „Domine Iesu” (Lord Jesus), which corresponds to the first part of the Hesychast formula: „Lord Jesus Christ ..."48.

${ }^{45}$ The first chapter of the Letter to the Believers, titled „About those who make repentance”, characterizes them as those who „love the Lord with all his heart, with all his soul and mind, with all his might, and love their neighbor as themselves". The second chapter, titled "About those who do not repent" shows them as those who ,do not have spiritual wisdom, because they do not have the Son of God, which is the true wisdom of the Father".

${ }^{46}$ SAN FRANCESCO D'ASSISI, Letter to the believers, 48-50, in FF 200, p. 155

${ }^{47}$ IDEM, Testament 5-7 in FF 111, p. 131.

${ }^{48}$ Leonhard LEHMANN, op. cit., p. 63-64. 
Significant is also how St. Francis begins his letter to the whole order of the minor brethren: ,... Brother Francis, a weak and feeble man, your lowest servant, wishes you health in Him who has redeemed us, He washed us in his precious blood. Hearing his name, adore him with fear and reverence, forsaken to the ground: Jesus Christ, the Son of the Most High is his name, which is blessed for ever" 49 .

This is a worship confession of the name of „the Lord Jesus Christ, the Son of the Most High". In this letter we literally find the first part of Jesus' prayer and, even more surprisingly, the recommendation to the brothers that when they hear this name to „worship Him". We know the Orthodox tradition that the utterance of Jesus' prayer is also combined with the great prostrations, after a certain number of invocations.

The Saint's biographers confess quite frequently his particular devotion to the name of Jesus. Tommaso da Celano reminds that every time when he pronounced this name "he passed the tongue on his lips, almost to taste and retain the sweetness of those words" 50 .

The same biographer describes with continuous emotion the meditation of St. Francis to the name of Jesus in his heart. The text is an uplifting one:

„The brothers who lived with him know very well that every day, more, every moment the memory of Christ was blossoming on his lips; with how much suaveness and sweetness he spoke to, with how much loving love he was talking to Him. The mouth spoke from the abundance of the holy feelings of the heart, and that source of enlightened love that filled it inside went outside. He was

49 SAN FRANCESCO D'ASSISI, Letter to the general chapter and to all the brothers 86, in FF 470, p. 478-479.

${ }^{50}$ TOMMASO da Celano, First life of St. Francis of Assisi 86, in FF 470, p. 478479. 
really very busy with Jesus. He always wore Jesus in his heart, Jesus on his lips, Jesus in his ears, Jesus in the eyes, Jesus in his hands, Jesus in all the other limbs. Whenever, while sitting at the table, hearing and pronouncing the name of Jesus, forgetting the temporal food, and how we read about a saint, ,looking not seeing and listening did not hear". And, more than ever, being on the journey and meditating on Jesus or singing, forget that he is on the journey and stops inviting all creatures to praise Jesus. And because he always carries and keeps in his heart admirable love in Christ, and he crucified, that is why he was entrusted with His image more than anyone else, because he had the gift of contemplation during the ecstasy in glory unspoken and incomprehensible sitting, at the Father's right" ${ }^{\text {"51. }}$.

Here we have the testimony, which we encounter in the case of the hesychast prayer, of a continuous memory of Jesus, which brings with him the worthiness of a contemplative view of Him in shrouded glory.

In the preceding text, we have almost the traditional formula of the hesychast prayer, remembering the presence of tranquility and solitude, of the joy of the heart and of the light that floods it, all the elements that characterize the spirituality of hesychast and which we find expressed in a very explicit manner.

The fact that St. Francis chose as a way of living for himself and his brothers the apostolic activity and not the strictly eremitic does not very much involve in the sense of union with God through prayer, because the brothers are asked as even then when they are on the journey to live and pray as if they were in a monastery: „In the name of the Lord, walk two by two in the streets with dignity, keeping quiet in the morning and until after the third hour, praying to the Lord in your hearts. No discussion devoid of profundity and superficiality between you, because even if you are traveling, your

${ }^{51}$ Ibidem, 115, in FF 522, p. 506. 
behavior must be received as if it were in a monastery or in a hermitage. Wherever we are or move we carry with us our hermitage: brother body, the soul being the hermit who lives inside praying to God and meditating. And if the soul does not live serenely and solitarily in his hermitage, by little importance is for the brother the hermitage build by man's hand" 52 .

The hesychasm is also known as the ,spirituality of the hermitage"; the real hermitage is the chamber of your own heart. In this sense, the words of St. Gregory Palamas, the one who is called the theologian of the hesychasm, are explicit: „We work with the body and pray with the mind; our outer man to fulfill his fleshly obligations, the inner man must be totally devoted to the ministry of God, never to let this exercise of mental prayer, according to what Jesus, God and Man has commanded us: «When you pray, go into your chambers ...» (Matthew 6: 6). The chamber of the soul is the body; the doors are the five senses. The soul enters the pantry when the mind ceases to walk up and down",53.

Another common aspect of St. Francis and the hesychasts is the predilection for light. In his prayers we find a rich experience of light. To him God is light because the angels are enlightening ${ }^{54}$, praying so that the shadows of his heart are illuminated $^{55}$ until His knowledge is made in the light ${ }^{56}$.

$52 * * *$ The perugian legend 80 in FF 1636, p. 1246.

53 Text available at Jean MEYENDORFF, San Gregory Palamas and the Orthodox mysticism [St. Grégoire Palamas et la mystique orthodoxe] translation by the Bose monastery community, Milan, Gribaudi Editor, 1997, p. 61.

${ }^{54}$ SAN FRANCESCO D'ASSISI, Commentary on the «Pater noster» 2 in FF 267, p. 180: „Who are in heaven: in Angels and Saints, enlightening them to know that You, Lord, are Light...”.

${ }^{55}$ IDEM, Prayer before the Crucifix, in FF 276, p. 182: „Exalted and glorified God, enlighten the darkness of my heart, give me righteousness faith, sure 
St. Francis' biographies tell us about the phenomenon of light that enveloped the saint when he prayed. This is a phenomenon known to the mystical hesychasts, which is one of the highest gifts that can be received as a result of the earnest prayer. The testimony is found at Bonaventure: „As he prayed at night, he was seen with his cross-shaped hands raised from the ground with his whole body and surrounded by a luminous cloud: a wonderful light spread around his body, which in a wonderful way had confessed the bright light in his soul" ${ }^{17}$.

\section{Conclusions}

Facing the characteristics of the Hesychaast movement with the elements of Franciscan spirituality we come to the conclusion that we can find some similarity, especially since in many aspects St. Francis differs from the Western spirituality that despises the world to express the cosmic vision, specific oriental, which sees the world transfigured by the Resurrection. From this reporting to the world there are other Orthodox specific points: Christocentrism and the role of the Holy Spirit within a trinitarian vision of $\mathrm{God}^{58}$.

Although it can not be demonstrated the existence of historical contacts between St. Francis and the Orthodox world, many Catholic and Orthodox theologians who have analyzed the personality of the Saint of Assisi have testified that it is a synthesis or a bridge between the Eastern and the Western

hope and perfect love, wisdom and knowledge, Lord, to fulfill your holy and true commandment. Amen."

${ }^{56}$ IDEM, Commentary on the «Pater noster» 2 in FF 268, p. 180: „, hallowed be

Your name: let the knowledge shine forth in us, that we may understand the extent of thy blessings ..."

${ }^{57}$ SAN BONAVENTURA da Bagnoregio, Major legend X, 4, in FF 1180, p. 921.

58 Giuseppe Alberico Possedoni (coord.), Saint Francis and the Orient. Beyond words, Padua, Messaggero Edotions, 2003, p. 146-147. 
world, which also applies to spirituality. Thus, it was said that the rebirth of Christianity could be accomplished much easier in all its freshness and original beauty, if ,the meeting between the Franciscan spirit and the spirit of Orthodoxy is achieved" 59. Olivier Clément asks: „If franciscanism, turning to its roots, could not conceive to find the true theological foundations in pnevmatology and Orthodox cosmology. At the same time, if freshness, franciscan spontaneity, humankind and poetry are unable to help the Orthodox to overcome the persistent temptations of ritualism, of a too repetitive theology, leading it to overcome that type of monophysism - born in periods of decadence and immobility because of fear - which does not open to man all the space that belongs to him" 60 .

We conclude with the characterization made by the Romanian apologist Ioan Gheorghe Savin of Saint Francis of Assisi, to whom he dedicates the most part of his Western mystic course held in the middle of the last century at the Faculty of Orthodox Theology in Bucharest: „Although Francis of Assisi was not a speculative mystic, it was one of the rare examples that lived the mystical-ascetic life in all its depth, making the life of the Gospel as the target of all the mystics as Francis's goal... As a practitioner of Jesus' prayer and of the prayer of the mind, we saw the supreme physical sweetness that the name of Jesus caused him, as we have seen him so often in immersion without words, but by the total abduction of contemplative prayer, to which he it was the only retreat not only from Mount Alvernia, but many times when he prayed, beginning at dawn and so many times during the day and night. Arranged by purification and enlightenment at the

59 Olivier ClÉMENT, „From the other shores: the Orthodox”, in Luigi SANTUCCI (coord.), Francesco: eight centuries of a great Christian adventure, Milan, Arnoldo Mondadori Publishing House, 1981, p. 101.

${ }^{60}$ Ibidem . 
supreme stage of infusing the three theological virtues, he mades from the virtue of God's love, of man and nature, the permanence of his way of being, so in Francis of Assisi we have one of the brilliant examples of life and knowledge mystical" ${ }^{161}$.

\section{References}

1. The holy bible or the Holy Scripture, Bucharest, Publishing House of the Romanian Orthodox Church Bible and Mission Institute IBMBOR, 2001.

2. BALDINI, Massimo (coord), The silent in the Desert Fathers, Vicenza, La Locusta House Publishing, 1987.

3. SAN BONAVENTURA da Bagnoregio, Major legend, in Franciscan Sources 1020-1329, p. 827-1014.

4. BRUNINI, Marcello The prayer of the heart in the spirituality of the Christian East, Padua, Messaggero Editions, 1997.

5. ClÉMENT, Olivier, „From the other shores: the Orthodox”, in Luigi Santucci (coord.), Francesco: eight centuries of a great Christian adventure, Milan, Arnoldo Mondadori Publishing House, 1981.

6. EsSER, Kajetan, Admonitions of S. Francis, Rome, A.S.S.C. Editions, 1982.

7. SAN FRANCESCO D'ASSISI, „Admonitions”, in Franciscan Sources 141-178, p. 137-148.

8. IDEM, „Commentary on the «Pater noster»”, in Franciscan Sources 266-275, p. 180-181.

9. IDEM, „Letter to the believers”, in Franciscan Sources 179-206, p. 151-158.

10. IDEM, „Letter to the general chapter and to all the brothers”, in Franciscan Sources 214-233, p. 162-167.

11. IDEM, „Praise of God Most High”, in Franciscan Sources 261, p. 176-177.

61 Ioan Gheorghe SAVIN, Western mysticism, introduction by Antonie PlămĂdEALĂ, Sibiu, The Printing of the Eparchial Printing House, 1996, pp. 103-104. 
12. IDEM, Prayer before the Crucifix, in Franciscan Sources 276, p. 182.

13. IDEM, Confirmed rule, in Franciscan Sources 74-109, p. 123130.

14. IDEM, Unconfirmed Rule, in Franciscan Sources 1-73, p. 99122.

15. IDEM, Testament, in Franciscan Sources 110-131, p. 131-134.

16. *** I Fioretti by S. Francis, in Franciscan Sources 1826-1958, p. 1441-1624.

17. Saint John ClimaCus, The Ladder of Divine Ascent. The book about the needs [col. Philocalia, vol. IX], translation from Greek, introduction and notes by Dumitru Stăniloae, Bucharest, Humanitas Publishing House, 2011.

18. LEHMANN, Leonhard, Francis, teacher of prayer, translation from German into Italian by Flaviano Premoli and Pietro Maranesi, Rome, Historical Institute of the Capuchins, 1993.

19. LELOIR, Louis, Desert and communion: the Fathers of the desert and their message today, presentation by Enzo Bianchi, translate from French into Italian by Maria Paronelli, Turin, Gribaudi Edition, 1982.

20. *** The perugian legend in *** Franciscan Sources 15451676, p. 1155-1289.

21. Leloup, Jean-Yves, The Hesychasm - what is it and how it lives, translation from French into Italian by Rosalba Giugni, Torino, Piero Gribaudi Editore, 1992.

22. MEYENDORFF, Jean, San Gregory Palamas and the Orthodox mysticism [St. Grégoire Palamas et la mystique orthodoxe] translation by the Bose monastery community, Milan, Gribaudi Editor, 1997.

23. OlgIATI, Feliciano et alii (eds. / coord.), Franciscan sources. Writings and biographies of St. Francis of Assisi. Chronicles and other testimonies of the first Franciscan century. Writings and biographies of St. Clare of Assisi [Fonti Francescane. Scritti e biografie di san Francesco d'Assisi. Cronache e altre testimonianze del primo secolo francescano. Scritti e biografie di santa Chiara d'Assisi], Padua, Messaggero Editions, 1982. 
24. *** Egyptian patericon, Alba Iulia, Reîntregirea Publishing House, 2014.

25. POSSEDONI, Giuseppe Alberico, (coord.), Saint Francis and the Orient. Beyond words, Padua, Messaggero Edotions, 2003.

26. SAVIN, Ioan Gheorghe, Western mysticism, introduction by Antonie PlămăDEală, Sibiu, The Printing of the Eparchial Printing House, 1996.

27. ŠPIDLíK, Tomáš, „The Hesychast” în Guerrino PeLLICCIA / Giancarlo RocCA, Dictionary of Institutes of Perfection, vol. III, Rome, Paoline Editions, 1976, p. 1312-1313.

28. IDEM, „The prayer of the heart. A comparison between East and West", in Yannis SPITERIS / Bruno GIANESIN (coord.), Seeing God. Meeting between East and West, Bologna, Dehoniane Editions, 1994, p. 63-82.

29. SPITERIS, Yannis, Francis and the Christian East. A comparison, Rome, Historical Institute of the Capuchins Edition, 1999.

30. Tommaso da Celano, First life of St. Francis of Assisi in Franciscan Sources 315-571, p. 401-531.

31. IDEM, Second life of St. Francis of Assisi in Franciscan Sources 578-820, p. 537-732.

32. Saints VARSANUFIE AND JOHN, Spiritual Letters [col. Philocalia, vol. XI], translation from Greek, introduction and notes by Dumitru Stăniloae, Bucharest, Humanitas Publishing House, 2009.

33. Kalistos WARE, The Power of the Name: The Jesus Prayer in Orthodox Spirituality, 1986, translate from English into Italian by Elisabetta Capello abd Marino Clerico, in Elisabeth BEHRSIGEL, The place of the heart. Initiation to Orthodox spirituality, Milan, Paoline Editions, 1993.

\section{Web sources:}

1. Moldoveanu, John, Bibliography of the Romanian hesychasm, available on www.unibuc.ro/prof/moldoveanu_i/docs/res/2012ianIsihasmul. doc (accessed on 03.08.2018). 